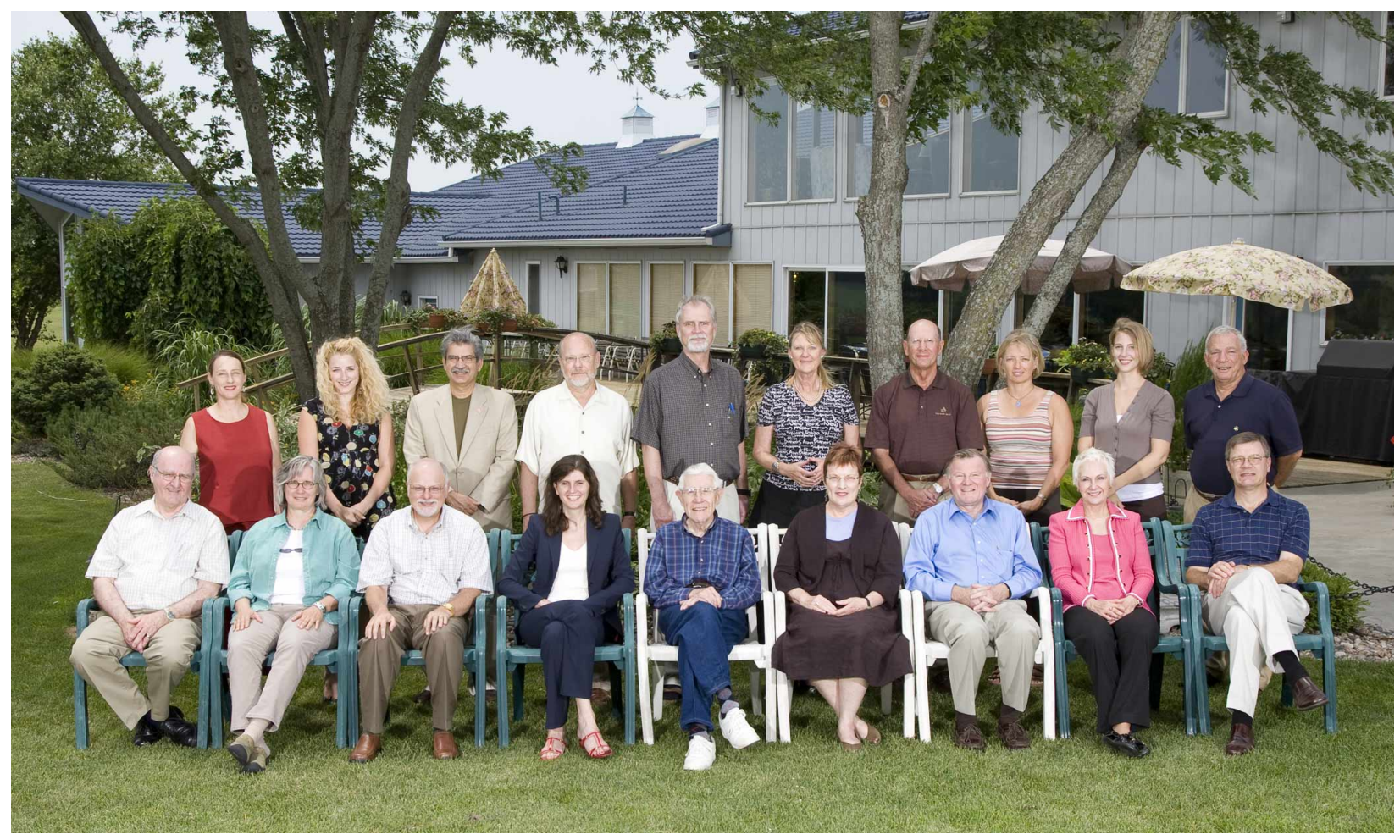

standing, left to right: Evelyn Haaheim, Kate Wolff, Prem Paul, Jack Schultz, Jim Guikema, Barbara Timmermann, Paul Terranova, Susan Brown, Megan Blossom, Sam Enna seated, left to right: Brian Foster, Melinda Merrill, Joe Steinmetz, Marion Mueller, Dick Schiefelbusch, Mabel Rice, David Lightfoot, Barbara Couture, Steve Warren conference photos by Steve Puppe 


\section{CONFERENCE PARTICIPANTS 2008}

\section{Keynote Speakers}

David Lightfoot, Ph.D., Assistant Director, NSF. Directorate for Social, Behavioral, and Economic Sciences

Marion Müller, Ph.D., Director, North American Office, German Research

Foundation

\section{Kansas State University}

Susan Brown, Ph.D., Professor of Biology

Jim Guikema, Ph.D., Associate Vice President for Research

\section{The University of Kansas}

Salvatore Enna, Ph.D., Associate Dean for Research and Graduate Education, University of Kansas Medical Center

Mabel L. Rice, Ph.D., The Fred \& Virginia Merrill Distinguished Professor of Advanced Studies and Director of the Merrill Center

Richard Schiefelbusch, Ph.D., Director Emeritus of the Schiefelbusch Institute for

Life Span Studies and the Merrill Center, and Merrill Board member

Joseph Steinmetz, Ph.D., Dean of the College of Liberal Arts and Sciences

Paul Terranova, Ph.D.,Vice Chancellor for Research, University of Kansas Medical

Center

Steven F. Warren, Ph.D., Vice Provost for Research \& Graduate Studies, and Merrill

Board member

\section{University of Missouri}

Brian Foster, Ph.D., Provost

Jack Schultz, Ph.D., Director, Christopher S. Bond Life Sciences Center

\section{University of Nebraska - Lincoln}

Barbara Couture, D. A., Senior Vice Chancellor for Academic Affairs

Prem Paul, D.V.M., Ph.D., Vice Chancellor for Research

\section{Other Participants}

Melinda Merrill, Merrill Advanced Studies Center Board Member

Kate Wolff, Office of the Governor of Kansas 